Bull. Chem. Soc. Ethiop. 2021, 35(3), 513-524.

(c) 2021 Chemical Society of Ethiopia and The Authors

ISSN 1011-3924

DOI: https://dx.doi.org/10.4314/bcse.v35i3.4

Printed in Ethiopia

Online ISSN 1726-801X

\title{
PREPARATION, SPECTRAL STUDY AND ANTIMICROBIAL ACTIVITY OF BINARY CO(II) COMPLEXES DERIVED FROM 2'-HYDROXY CHALCONES
}

\author{
Pravinkumar Patil ${ }^{1}$ and Sainath Zangade ${ }^{2 *}$ \\ ${ }^{1}$ Research Laboratory, Department of Chemistry, N.E.S. Science College, Nanded-431605(M S) \\ India \\ ${ }^{2}$ Department of Chemistry, Madhavrao Patil, ACS College, Palam, District Parbhani-431720
}

(M S) India

(Received September 21, 2020; Revised March 7, 2021; Accepted November 22, 2021)

\begin{abstract}
The present work comprises preparation, characterization, thermal behavior and growth inhibitory activity of some novel Co(II) complexes derived from substituted $(E)$-1-(1-hydroxy-4-iodonaphthalen-2-yl)-3phenylprop-2-en-1-one (L1) and (E)-1-(4-bromo-1-hydroxynaphthalen-2-yl)-3-phenylprop-2-en-1-one (L2-L6). Newly synthesized metal-ligand complexes were structurally confirmed with suitable spectroscopic technique such as FT-IR, EPR, NMR (both ${ }^{1} \mathrm{H}$ and ${ }^{13} \mathrm{C}$ ). XRD analysis for complex $\mathbf{C 1}$ confirmed the crystal system; tetragonal and space group; P 42/n: 2 with unit cell dimensions a, $\mathrm{b}=13.3516 \AA, \mathrm{c}=10.8009 \AA ; \alpha, \beta, \gamma=90^{\circ}$. The IR and EPR study demonstrated that interaction between metal ions and ligand occurs through carbonyl oxygen and hydroxyl oxygen. From the values of magnetic moment $(\mu)$ it was observed that synthesized complexes (C1-C6) are paramagnetic with three unpaired electrons contain one electron in $t_{2 g}$ orbital and two electrons in $\mathrm{e}_{\mathrm{g}}$ orbitals. Further all these complexes have been evaluated in-vitro for their antimicrobial activity against the Gram positive bacteria Staphylococcus aureus, Gram negative bacteria Escherichia coli and the yeast Candida albicans. The complex $\mathbf{C 1}$ showed the significant antimicrobial activity, whereas the complexes $\mathbf{C 2}, \mathbf{C 4}, \mathbf{C 5}$ and $\mathbf{C 6}$ are moderately active against the tested pathogens. The antimicrobial data revealed that growth inhibitory activities of complexes were enhanced comparatively than its respective ligands. The enhanced antimicrobial activity is attributed to the presence of halogens $(\mathrm{Br}, \mathrm{Cl}, \mathrm{I})$ and hydroxyl $(\mathrm{OH})$ active substituents associated with the basic nucleus of complexes. Therefore, the present study helps to develop a new class of antimicrobial analogues.
\end{abstract}

KEY WORDS: Metal complexes synthesis, 1,3-Diaryl-2-propene-1-one, Crystal structure, Thermal properties, Antimicrobial activity

\section{INTRODUCTION}

Chalcone occurring naturally in many plants or they can also be synthetically prepared in laboratory [1]. They are biogenic key precursors of flavonoids in higher plants [2, 3]. Chalcones are important reactive intermediate to constitute a major class of oxygen containing heterocyclic compounds [4]. The chalcones and their related derivatives are well-known for wide range of biological activities such as antiviral [5], anti-inflammatory [6], antitumor [7], antimitotic [8], antimicrobial [9], antioxidant [10], anti-diabetic [11] and antimalarial [12] activities. The reason for biological activity may be due to the presence of reactive keto vinyl group which allows for interference with cell membrane of fungi and moulds and demonstrates static properties against pathogens [13].

1,3-Diaryl-2-propene-1-one compounds possess the reactive keto-ethylenic group which interconverts to its isomeric form using acid or alkali makes them important ligands $[14,15]$. Chalcones are effective metal ion chelators and can easily form metal-coordinated complex compounds. All types of chalcones possess three domains to react with metals such as functional groups present on aromatic ring, keto-enol moiety and olefinic moiety [16]. 2'-hydroxy chalcones, their related heterocyclic and naphthalene analogues have reported for binding ability to form coordination complexes [17]. In recent years, the metal ions play important role in living systems and various transition metal complexes have been used as medicinal compounds. Metal

*Corresponding author. E-mail: drsbz@rediffmail.com

This work is licensed under the Creative Commons Attribution 4.0 International License 
complexes possess great diversity in their action like anticancer [18], anti-inflammatory [19], antimycotic [20], anti-alzheimer [21], anti-oxidant, anti-microbial [22] and anti-diabetic [23] properties. Metal ions play vital roles in biological processes, for instance the divalent magnesium and calcium ions play important regulatory roles in cells. In fact, on coordination, ligands would enhance their bioactive profile or some inactive ligand could possess medicinal properties [24]. $\mathrm{Co}(\mathrm{II})$ ion is one of the important element in the transition element series, being involved in the many coordination complexes due to higher empty $3 d$-orbital. Redox behaviour of Co(II) complexes has medicinal application as biosensor, also redox-active element may lead to a new route in drug designing. Cobalt is an essential trace element, apart from being an important part of vitamin $\mathrm{B}_{12}$ form, the presence of cobalt is necessary to play a decisive role in generating neurotransmitters [25-26]. Various Co(III) complexes have been reported with antimicrobial activities [27] and anticancer activities [28]. Co(II) complexes of the Schiffs bases had been reported for their antimicrobial and antifungal properties. In view of the above importance of metal complexes first time, we have synthesized the metal complexes of $\mathrm{Co}$ (II) and chalcones and evaluated them for their antimicrobial activities.

\section{EXPERIMENTAL}

\section{Chemical material and apparatus}

Starting materials, solvents and reagents were purchased from commercial sources and were used without purification. FTIR spectra were recorded as KBr pellets on a Perkin Elmer System 2000. ${ }^{1} \mathrm{H}$ NMR and ${ }^{13} \mathrm{C}$ NMR spectra were acquired in dimethylsulfoxide solvent on a Bruker Avance NEO500 Spectrometer at $500 \mathrm{MHz}$. TGA analysis was performed on the instrument Mettler Toledo in an inert atmosphere. XRD was measured on an instrument X-ray diffractometer, Ultima IV, Rigaku corporation. ESR analysis was performed on the instrument ESR-JEOL, JES-FA200 ESR spectrometer with $\mathrm{X}$ band $(8.75-9.65 \mathrm{GHz})$ at room temperature. In our previous work, we have reported the synthesis of ligand 1,3-diaryl-2-propene-1-one derivatives [29].

General procedure for synthesis of ligand 1,3-diaryl-2-propene-1-one derivatives

A mixture of substituted 2-hydroxy acetonaphthone $(0.01 \mathrm{~mol})$ and substituted benzaldehyde $(0.01 \mathrm{~mol})$ were dissolved in $20 \mathrm{~mL}$ of 2-methoxyethanol. Weighed accurately and transferred $0.02 \mathrm{~mol}(4.24 \mathrm{~g})$ of anhydrous $\mathrm{K}_{3} \mathrm{PO}_{4}$ in to reaction solution. The reaction mixture was refluxed for 5 hours and progress of the reaction was monitored by TLC in hexane: ethyl acetate $(4: 1)$. After completion of refluxing, reaction mixture was cooled and poured into $20 \mathrm{~mL}$ of ice-water, stirred then treated with dil. $\mathrm{HCl}$ to precipitate crude solid product. Solid mass observed were filtered, washed with sufficient amount of water and dried under vacuum. The crude product was purified by column chromatography to give pure sample.

\section{General procedure for synthesis of metal complex $\left[\mathrm{Co}(\mathrm{Ln})_{2} \cdot 2 \mathrm{H}_{2} \mathrm{O}\right]$ complex}

The cobalt chloride solution of $0.25 \mathrm{mmol}$ was prepared from $\mathrm{CoCl}_{2} \cdot 6 \mathrm{H}_{2} \mathrm{O}$ in $10 \mathrm{~mL}$ of methanol. The ligand solution of $0.50 \mathrm{mmol}$ was prepared in $20 \mathrm{~mL}$ of methanol and set the $\mathrm{pH}$ of the solution around 7.0-8.0 with dilute $\mathrm{NaOH}$ solution. To this ligand solution, the metal salt solution was added dropwise with constant shaking in a round bottom flask. Then the mixture was refluxed for $3 \mathrm{~h}$, the obtained product was filtered off, washed with $20 \mathrm{~mL}$ warm methanol and dried at room temperature. The schematic representation for complex formation is outlined in Scheme 1. All the synthesized complexes were characterised by instrumental analysis. 
Preparation and spectral study of binary Co(II) complexes derived from 2'-hydroxy chalcones 515

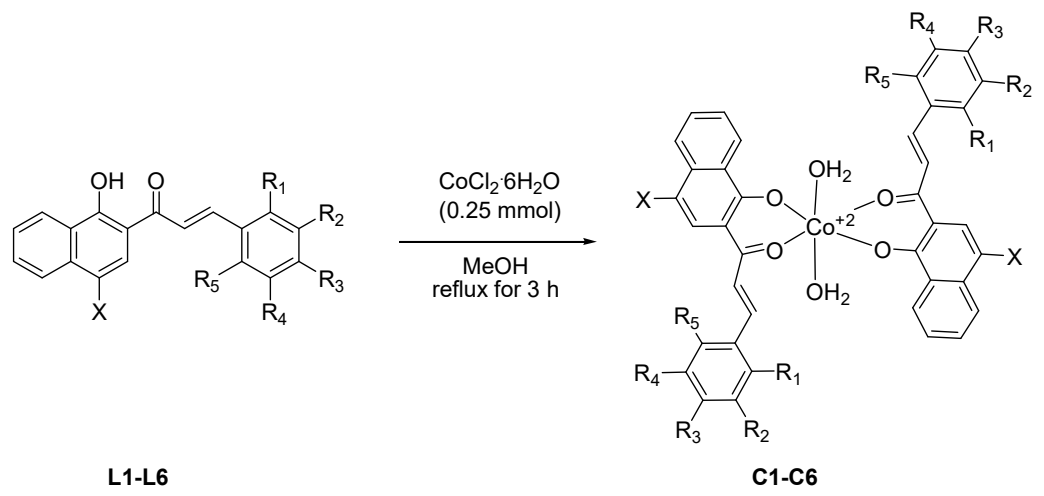

$$
\begin{array}{ll}
\text { C1: } \mathrm{R}_{1}, \mathrm{OH} ; \mathrm{R}_{2}, \mathrm{R}_{4}, \mathrm{I} ; \mathrm{R}_{3}, \mathrm{R}_{5}, \mathrm{H} ; \mathrm{X}, \mathrm{I} & \mathrm{C} 4: \mathrm{R}_{1}, \mathrm{R}_{5}, \mathrm{Cl} ; \mathrm{R}_{2}, \mathrm{R}_{3}, \mathrm{R}_{4}, \mathrm{H} ; \mathrm{X}, \mathrm{Br} \\
\mathrm{C2}: \mathrm{R}_{1}, \mathrm{R}_{2}, \mathrm{R}_{4}, \mathrm{R}_{5}, \mathrm{H} ; \mathrm{R}_{3}, \mathrm{Cl} ; \mathrm{X}, \mathrm{Br} & \mathrm{C} 5: \mathrm{R}_{1}, \mathrm{R}_{3}, \mathrm{Cl} ; \mathrm{R}_{2}, \mathrm{R}_{4}, \mathrm{R}_{5}, \mathrm{H} ; \mathrm{X}, \mathrm{Br} \\
\mathrm{C} 3: \mathrm{R}_{1}, \mathrm{R}_{2}, \mathrm{R}_{4}, \mathrm{R}_{5}, \mathrm{H} ; \mathrm{R}_{3}, \mathrm{Br} ; \mathrm{X}, \mathrm{Br} & \mathrm{C6}: \mathrm{R}_{1}, \mathrm{R}_{4}, \mathrm{R}_{5}, \mathrm{H} ; \mathrm{R}_{2}, \mathrm{R}_{3}, \mathrm{OH} ; \mathrm{X}, \mathrm{Br}
\end{array}
$$

Scheme 1. Schematic representation of synthesis of binary of $\mathrm{Co}^{2+}$ octahedral complexes C1-C6.

Diaquobis((2-((E)-3-(2-hydroxy-3,5-diiodophenyl)acryloyl)-4-iodonaphthalen-1-l)oxy)cobalt(II) (C1). FT-IR (KBr, v, cm $\left.{ }^{-1}\right)$ : $3449.9\left(\mathrm{H}_{2} \mathrm{O}\right), 1636.5(\mathrm{C}=\mathrm{O}), 1596.2(\mathrm{C}=\mathrm{C}), 1241.5(\mathrm{C}-\mathrm{O}), 578.7(\mathrm{Co}-$ O); ${ }^{1} \mathrm{H}$ NMR (500 MHz, DMSO, $\left.\delta / \mathrm{ppm}\right): 5.37(2 \mathrm{H}, \mathrm{s}), 7.21(2 \mathrm{H}, \mathrm{d}, J=16 \mathrm{~Hz}), 7.61(2 \mathrm{H}, \mathrm{d}, J=$ $16 \mathrm{~Hz}), 7.76-8.29(14 \mathrm{H}, \mathrm{m}) ;{ }^{13} \mathrm{C}$ NMR (125 MHz, DMSO, $\left.\delta / \mathrm{ppm}\right): 83.2,99.5,103.2,117.1,112.5$, $128.9,138.5,140.2,143.7,146.2,151.4,153.3,157.7,162.8,180.6,184.2$.

Diaquobis ((4-bromo-2-((E)-3-(4-chlorophenyl) acryloyl)naphthalen-1-yl)oxy)cobalt(II) (C2). FT-IR $\left(\mathrm{KBr}, v, \mathrm{~cm}^{-1}\right)$ : $3429.8\left(\mathrm{H}_{2} \mathrm{O}\right), 1588.6(\mathrm{C}=\mathrm{O}), 1525.0(\mathrm{C}=\mathrm{C}), 1248.2(\mathrm{C}-\mathrm{O}), 571.6(\mathrm{Co}-\mathrm{O})$; ${ }^{1} \mathrm{H}$ NMR (500 MHz, DMSO, $\left.\delta / \mathrm{ppm}\right): 7.29(2 \mathrm{H}, \mathrm{d}, J=16 \mathrm{~Hz}), 7.73(2 \mathrm{H}, \mathrm{d}, J=16 \mathrm{~Hz}), 7.83-8.59$ $(18 \mathrm{H}, \mathrm{m}) ;{ }^{13} \mathrm{C}$ NMR $(125 \mathrm{MHz}, \mathrm{DMSO}, \delta / \mathrm{ppm}): 99.8,103.1,108.8,123.9,132.4,144.2,147.9$, $158.65,174.2,178.2,186.2$.

Diaquobis ((4-bromo-2-((E)-3-(4-bromophenyl) acryloylnaphthalen-1-yl)oxy)cobalt(II) (C3). FT-IR $\left(\mathrm{KBr}, v, \mathrm{~cm}^{-1}\right)$ : $3415.9\left(\mathrm{H}_{2} \mathrm{O}\right), 1578.9(\mathrm{C}=\mathrm{O}), 1526.1(\mathrm{C}=\mathrm{C}), 1252.5(\mathrm{C}-\mathrm{O}), 576.7(\mathrm{Co}-\mathrm{O})$; ${ }^{1} \mathrm{H}$ NMR $(500 \mathrm{MHz}, \mathrm{DMSO}, \delta / \mathrm{ppm}): 7.26(2 \mathrm{H}, \mathrm{d}, J=16 \mathrm{~Hz}), 7.59(2 \mathrm{H}, \mathrm{d}, J=16 \mathrm{~Hz}), 7.66-8.47$ $(18 \mathrm{H}, \mathrm{m}) ;{ }^{13} \mathrm{C}$ NMR $(125 \mathrm{MHz}, \mathrm{DMSO}, \delta / \mathrm{ppm}): 98.4,102.2,106.2,118.2,125.4,134.3,141.5$, $144.3,154.5,161.2,171.4,182.1,189.3$.

Diaquobis ((4-bromo-2-((E)-3-(2,6-dichlorophenyl) acryloyl)naphthalen-1-yl)oxy)cobalt(II) (C4). FT-IR (KBr, v, cm $\left.{ }^{-1}\right): 3421.3\left(\mathrm{H}_{2} \mathrm{O}\right), 1583.0(\mathrm{C}=\mathrm{O}), 1526.5(\mathrm{C}=\mathrm{C}), 1248.1(\mathrm{C}-\mathrm{O}), 579.0$ (Co-O); ${ }^{1} \mathrm{H}$ NMR $(500 \mathrm{MHz}, \mathrm{DMSO}, \delta / \mathrm{ppm}): 7.18(2 \mathrm{H}, \mathrm{d}, J=16 \mathrm{~Hz}), 7.64(2 \mathrm{H}, \mathrm{d}, J=16 \mathrm{~Hz})$, 7.78-8.42 (16H, m); ${ }^{13} \mathrm{C}$ NMR (125 MHz, DMSO, $\left.\delta / \mathrm{ppm}\right): 98.5,105.4$, 107.5, 127.3, 133.0, 154.3, $156.6,161.6,169.4,172.4,184.1,187.4,189.9$.

Diaquobis((4-bromo-2-((E)-3-(2,4-dichlorophenyl)acryloyl)naphthalen-1-yl)oxy)cobalt(II)(C5). FT-IR $\left(\mathrm{KBr}, v, \mathrm{~cm}^{-1}\right)$ : $3434.1\left(\mathrm{H}_{2} \mathrm{O}\right), 1630.5(\mathrm{C}=\mathrm{O}), 1580.5(\mathrm{C}=\mathrm{C}), 1247.2(\mathrm{C}-\mathrm{O}), 580.6(\mathrm{Co}-\mathrm{O})$; ${ }^{1} \mathrm{H}$ NMR $(500 \mathrm{MHz}, \mathrm{DMSO}, \delta / \mathrm{ppm}): 7.41(2 \mathrm{H}, \mathrm{d}, J=16 \mathrm{~Hz}), 7.69(2 \mathrm{H}, \mathrm{d}, J=16 \mathrm{~Hz}), 7.75-8.67$ $(16 \mathrm{H}, \mathrm{m}) ;{ }^{13} \mathrm{C}$ NMR $(125 \mathrm{MHz}, \mathrm{DMSO}, \delta / \mathrm{ppm}): 96.2,106.3,105.4,124.5,134.2,152.8,158.5$, $162.8,166.4,175.2,182.3,189.6$.

Diaquobis((4-bromo-2-((E)-3-(3,4-dihydroxyphenyl)acryloyl) naphthalen-1-yl)oxy) cobalt(II)

(C6). FT-IR (KBr, v, cm $\left.{ }^{-1}\right): 3429.8\left(\mathrm{H}_{2} \mathrm{O}\right), 1617.4(\mathrm{C}=\mathrm{O}), 1591.7(\mathrm{C}=\mathrm{C}), 1249.8(\mathrm{C}-\mathrm{O}), 576.4$ 
(Co-O); ${ }^{1} \mathrm{H}$ NMR (500 MHz, DMSO, $\left.\delta / \mathrm{ppm}\right): 7.31(2 \mathrm{H}, \mathrm{d}, J=16 \mathrm{~Hz}), 7.70(2 \mathrm{H}, \mathrm{d}, J=16 \mathrm{~Hz})$, 7.82-8.64 (16H, m); ${ }^{13} \mathrm{C}$ NMR (125 MHz, DMSO, $\left.\delta / \mathrm{ppm}\right): 99.4,101.2,105.1,111.1,125.6,134.4$, $142.1,149.3,156.2,168.3,175.4,185.3,189.4$.

\section{Antimicrobial activity}

In vitro antimicrobial activity of compounds was determined by the agar cup plate method. The antibacterial activity was evaluated against the Gram positive bacteria Staphylococcus aureus (ATCC6538) and Gram negative bacteria Escherichia coli (ATCC8739) and the antifungal activity was evaluated against the Candida albicans (ATCC10231). The antibacterial standard drug Ampicilin and the antifungal standard drug Fluconazole was used for evaluation and result comparison. The stock solution of concentration $1 \mathrm{mg} / \mathrm{mL}$ of each compound and standard was prepared in dimethylsulfoxide. The Gram positive bacterial slant Staphylococcus aureus (ATCC6538) and Gram negative bacterial slant Escherichia coli (ATCC8739) were incubated at condition $35^{\circ} \mathrm{C}$ for $24 \mathrm{~h}$ in growth media soyabean casein digest agar. The fungal slant Candida albicans (ATCC10231) was incubated at condition $25^{\circ} \mathrm{C}$ for $72 \mathrm{~h}$ in growth media sabourauds dextrose agar. After incubation, well grown slant was inoculated in saline solution and vortexed to uniform suspension. Then, adjusted the O.D. with saline water at $530 \mathrm{~nm}$ on calorimeter and at viable count was $1 \times 10^{7}$ colony forming unit $(\mathrm{CFU} / \mathrm{mL})$. These culture suspensions were inoculated on Mueller-Hinton agar, and plates were bored by cork borer $(6 \mathrm{~mm})$ to create wells. From the stock solution, added a volume of $100 \mu \mathrm{L}$ of the sample solution in to each well. Two controls were maintained for each test. These included reference drug control and blank control. Then plates were incubated for bacteria at $35{ }^{\circ} \mathrm{C}$ for $24 \mathrm{~h}$ and for the yeast and mould incubated at $25{ }^{\circ} \mathrm{C}$ for $48 \mathrm{~h}$ to examine the zone of inhibition. All the experiments were performed in triplicate and the average zone of inhibition was reported.

Minimum inhibitory concentrations of each compound were determined against the standard concentrations. The agar dilution method was employed for the determination. Different concentrations of sample and standard such as $1.0,0.5,0.25$ and $0.12 \mathrm{mg} / \mathrm{mL}$ were prepared in dimethylsulfoxide by serial dilution. The volume of $100 \mu \mathrm{L}$ was added to each well. Standard and blank control was maintained for each test. After incubation, visually the lowest concentration of test solution with no detectable bacterial growth was considered as minimum inhibitory concentration.

\section{RESULTS AND DISCUSSION}

The ligand and its metal complexes were synthesized by the general procedure mentioned above in the experimental section. All the metal complexes are brown coloured in nature and are stable towards air and moisture at room temperature. All these metal complexes are insoluble in most of the organic solvents except DMSO and DMF. Metal complexes are characterized by FTIR, X-ray diffraction, TGA, ESR and NMR analysis.

\section{FT-IR spectra}

FT-IR measurement analysis of all the complexes was performed by potassium bromide pellet technique. The appearance of medium vibrational stretching band for $\mathrm{OH}$ group in ligand at 3230$3425 \mathrm{~cm}^{-1}$ [27] whereas strong and broad band at around $3400 \mathrm{~cm}^{-1}$ in metal complexes, confirms the formation of $\mathrm{Co}(\mathrm{II})$ complexes. The coordinated water molecule in the complex was confirmed by the presence of strong absorption broad band at $3415-3450 \mathrm{~cm}^{-1}$. The vibrational bands observed at $1578-1631 \mathrm{~cm}^{-1}, 1525-1597 \mathrm{~cm}^{-1}$ and $1241-1294 \mathrm{~cm}^{-1}$ demonstrated to corresponding functional groups $\mathrm{C}=\mathrm{O}, \mathrm{C}=\mathrm{C}, \mathrm{C}-\mathrm{O}$, respectively. Similarly, the characteristics band that appeared at $540-581 \mathrm{~cm}^{-1}$ demonstrates the $\mathrm{Co}-\mathrm{O}$ (metal-ligand) bond stretching present in formed metal complexes. 


\section{Powder X-ray diffraction analysis}

The X-ray powder diffraction analysis was performed on X-ray powder diffractometer with parameters scanning mode; 2 Theta/Theta, scanning type; continuous, X-ray; $40 \mathrm{kV} / 20 \mathrm{~mA}$, fixed monochromator with $2 \theta$ range 10 to 90 degree at step 0.01 degree. To observe the novelty of synthesized complex comparison was made between the observed pattern and reported pattern with peak search method. The observed pattern is shown in Figure 1. The measurement showed the peaks present at different $2 \theta$ values (Table 1). From these values calculated the grain size, dislocation density, strain and unit cell parameters and the values are shown in Table 2.

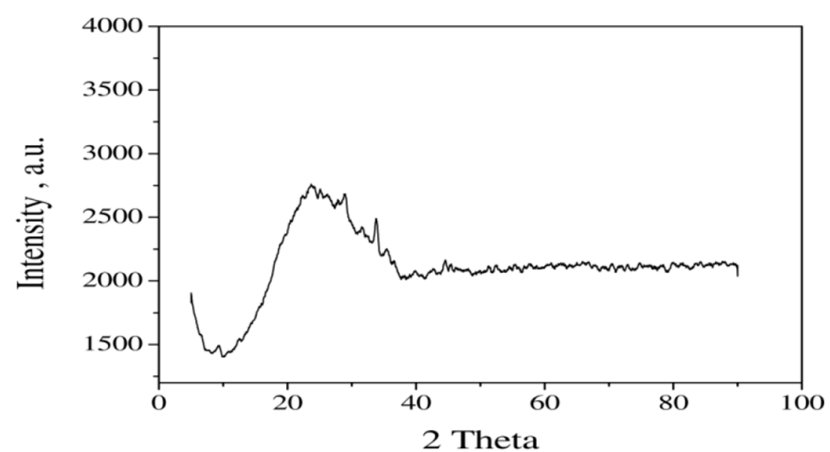

Figure 1. Indexed X-ray powdered diffraction peak for complex $\left[\mathrm{Co}\left(\mathrm{C}_{19} \mathrm{H}_{10} \mathrm{O}_{3} \mathrm{I}_{3}\right)_{2} \cdot 2 \mathrm{H}_{2} \mathrm{O}\right]$ (C1).

Table 1. 2 Theta values identified in XRD spectrum of complex C1.

\begin{tabular}{|c|c|c|c|c|}
\hline Pos. $\left[{ }^{\circ} 2\right.$ Th. $]$ & Height $[\mathrm{cts}]$ & FWHM $\left[{ }^{\circ} 2\right.$ Th. $]$ & d-spacing $[\AA]$ & hkl \\
\hline 9.36 & 21 & 0.09 & 9.44103 & 110 \\
\hline 25.1346 & 355.1 & 0.8801 & 3.5402 & 321 \\
\hline 28.7945 & 64.26 & 1.152 & 3.09801 & 213 \\
\hline 33.8416 & 130.26 & 0.384 & 2.64663 & 104 \\
\hline 44.5402 & 306.69 & 0.265 & 2.0326 & 215 \\
\hline 55.32 & 282.69 & 0.001 & 1.65933 & 741 \\
\hline 74.8394 & 283.34 & 0.1964 & 1.26767 & 952 \\
\hline
\end{tabular}

Table 2. Crystallographic data collection and structure refinement of complex C1.

\begin{tabular}{|l|l|}
\hline Complex & {$\left[\mathrm{Co}\left(\mathrm{C}_{19} \mathrm{H}_{10} \mathrm{O}_{3} \mathrm{I}_{3}\right)_{2} .2 \mathrm{H}_{2} \mathrm{O}\right]$} \\
\hline Empirical formula & $\mathrm{Co} \mathrm{C}_{38} \mathrm{H}_{20} \mathrm{O}_{6} \mathrm{I}_{6} .2 \mathrm{H}_{2} \mathrm{O}$ \\
\hline Formula weight & 1428.95 \\
\hline Temperature $(\mathrm{K})$ & 298 \\
\hline Crystal system & Tetragonal \\
\hline Space group & $\mathrm{P} 42 / \mathrm{n}: 2$ \\
\hline $\mathrm{a},(\AA)$ & 13.3516 \\
\hline $\mathrm{b},(\AA)$ & 13.3516 \\
\hline $\mathrm{c},(\AA)$ & 10.8009 \\
\hline$\alpha,\left(^{\circ}\right)$ & $90^{\circ}$ \\
\hline$\beta,\left({ }^{\circ}\right)$ & $90^{\circ}$ \\
\hline$\gamma,\left(^{\circ}\right)$ & $90^{\circ}$ \\
\hline Volume $\left(\AA^{3}\right)$ & 1925.42 \\
\hline $\mathrm{Z}$ & 2 \\
\hline$\rho$ calc $\left(\mathrm{g} / \mathrm{cm}^{3}\right)$ & 4.929 \\
\hline
\end{tabular}

Bull. Chem. Soc. Ethiop. 2021, 35(3) 


\begin{tabular}{|l|l|}
\hline$\mu\left(\mathrm{cm}^{-1}\right)$ & 193.133 \\
\hline Crystallite Size $(\mathrm{D}, \mathrm{nm})$ & 34.98051 \\
\hline Dislocation density $\left(\delta, \mathrm{nm}^{-2}\right)$ & 0.81724 \\
\hline Micro strain $(\varepsilon)$ & 8.50920 \\
\hline
\end{tabular}

Thermal gravimetric analysis

Thermal investigation of synthesized complexes was performed to know the information about thermal stability, the water molecule is present or absent inside or outside the coordination sphere of central metal ion and their thermal decomposition. TGA analysis was performed in a nitrogen inert atmosphere. In the first initial step complex started decomposing gradually till it attained the temperature of $170{ }^{\circ} \mathrm{C}$, which demonstrates the loss of coordinated water molecule. After $200{ }^{\circ} \mathrm{C}$ anhydrous complex started decomposing till the temperature around $950{ }^{\circ} \mathrm{C}$ which corresponds to the elimination of the ligand molecule. The total mass loss was around 69 to $74 \%$. The final residue left was around 26-31\% which corresponds to the formation of cobalt oxide. The overlaid thermogram pattern (Figure 2) of complexes C1, C2 and C5 is almost comparable; it indicates that studied complexes start to reduce their weight at a reasonably high temperature which signifies that the presence of water molecule is inside the coordination sphere of cobalt ion.

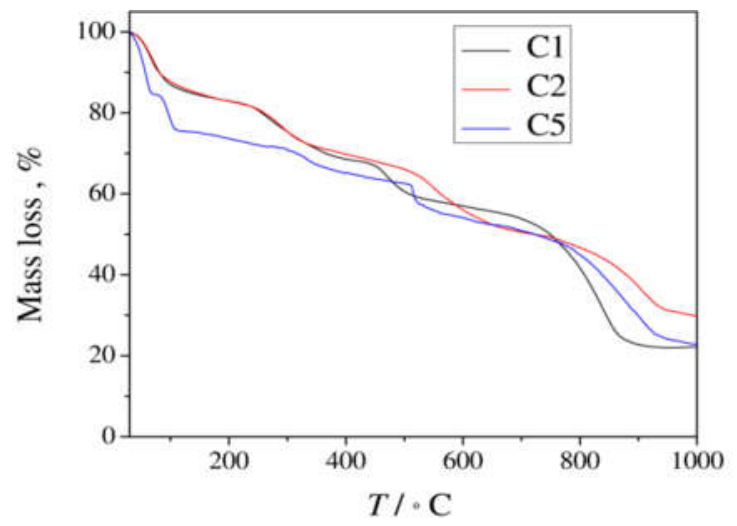

Figure 2. TGA curve for complex $\left[\mathrm{Co}\left(\mathrm{C}_{19} \mathrm{H}_{10} \mathrm{O}_{3} \mathrm{I}_{3}\right)_{2} \cdot 2 \mathrm{H}_{2} \mathrm{O}\right](\mathbf{C 1}),\left[\mathrm{Co}\left(\mathrm{C}_{19} \mathrm{H}_{11} \mathrm{O}_{2} \mathrm{ClBr}\right)_{2} \cdot 2 \mathrm{H}_{2} \mathrm{O}\right](\mathbf{C 2})$ and $\left[\mathrm{Co}\left(\mathrm{C}_{19} \mathrm{H}_{10} \mathrm{O}_{2} \mathrm{Cl}_{2} \mathrm{Br}\right)_{2} 2 \mathrm{H}_{2} \mathrm{O}\right](\mathbf{C 5})$.

EPR analysis

The EPR analysis of synthesized complexes was performed at room temperature. From the representative spectrum Figure 3, the calculated value of $g_{\| I}$ and $g_{\perp}$ are 2.0153 and 2.0066, respectively. The trend $\mathrm{g}_{\|}>\mathrm{g}_{\perp}>\mathrm{g}_{\mathrm{e}}$ observed for the complex, it designates that the observed complex has octahedral geometry and unpaired electron lies in $\mathrm{dx}^{2}-\mathrm{y}^{2}$ orbital.

\section{Magnetic moments}

Co(II) complexes are paramagnetic and exhibit magnetic moments at room temperature in the solid state. The Co(II) complexes showed the magnetic moments in the range 4.42-4.87 B.M., suggests three unpaired electron in octahedral environment. 


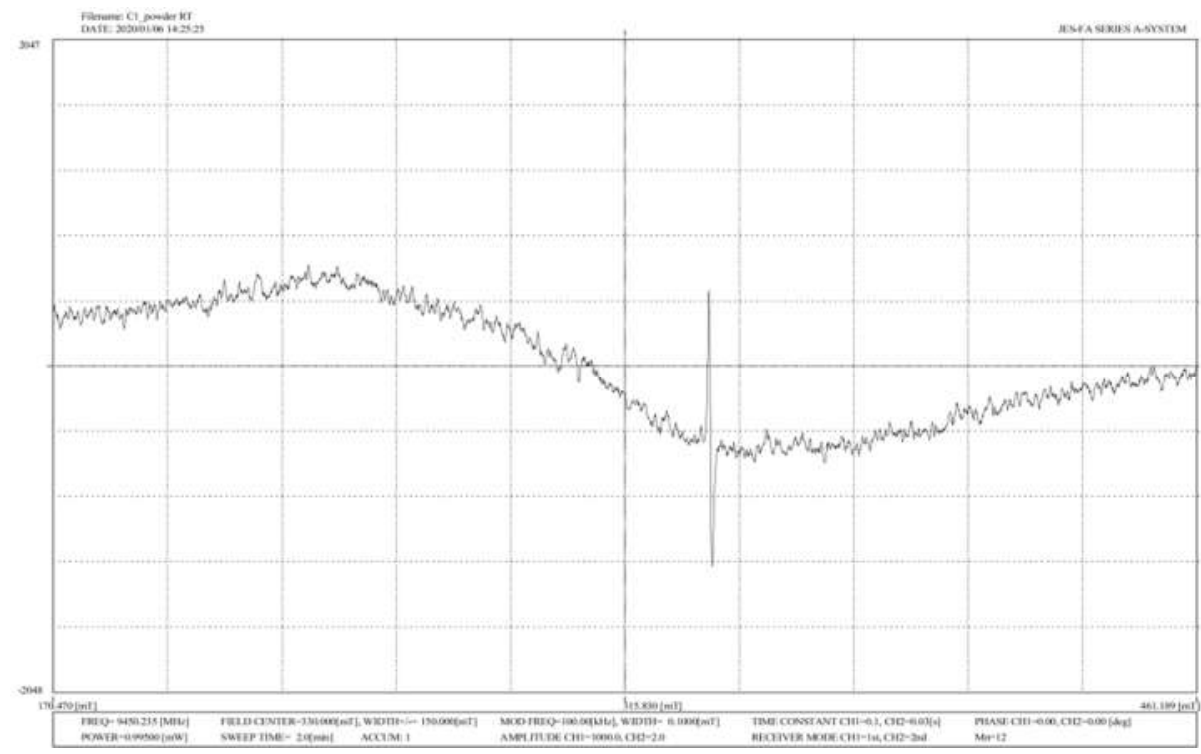

Figure 3. EPR spectrum of complex $\left[\mathrm{Co}\left(\mathrm{C}_{19} \mathrm{H}_{10} \mathrm{O}_{3} \mathrm{I}_{3}\right)_{2} \cdot 2 \mathrm{H}_{2} \mathrm{O}\right](\mathbf{C 1})$.

\section{${ }^{1} H N M R$ and ${ }^{13} C N M R$ analysis}

${ }^{1} \mathrm{H}$ NMR and ${ }^{13} \mathrm{C}$ NMR analyses were performed in dimethylsulfoxide. The representative spectra of complex $\mathbf{C 1}$ and corresponding ligand $\mathbf{L 1}$ are shown in Figure 4-6. In ${ }^{1} \mathrm{H}$ NMR analysis, the proton belonging to the aromatic ring displayed chemical shifts between $7.66-8.67 \mathrm{ppm}$. The characteristics peak at 7.18-7.41 ppm and 7.61-7.73 specify for $H_{\alpha}$ and $H_{\beta}$ protons of $\alpha, \beta-$ unsaturated carbonyl system with the coupling constant $J=16 \mathrm{~Hz}$. The peak at $\delta 5.37 \mathrm{ppm}$ signifies the presence of phenolic - $\mathrm{OH}$ group in coordination complex $\mathbf{C 1}$ and $\mathbf{C 6}$. While the absence of characteristic chemical shift for -OH proton of 2-hydroxy acetonaphthone moiety of ligand at $14.0 \mathrm{ppm}$ demonstrates that deprotonation of $-\mathrm{OH}$ and coordination occurs through the oxygen. In ${ }^{13} \mathrm{C}$ NMR analysis peaks appeared in the range 96.28 to $189.92 \mathrm{ppm}$ show the aromatic carbon, olefinic carbon and carbonyl carbon. While the peak at $\delta 83.25 \mathrm{ppm}$ demonstrates the carbon linked to -I substituent.

\section{Antimicrobial activity}

The in-vitro antimicrobial activity of complexes and their ligands are presented in Table 3 . The complexes $\mathbf{C 1}$ and $\mathbf{C 6}$ exhibit significant antibacterial activity against the pathogen Staphylococcus aureus, depicted the largest zone of inhibition $23.62 \mathrm{~mm}$ and $18.36 \mathrm{~mm}$, respectively, which were even higher than the zone of inhibition $18.14 \mathrm{~mm}$ of bactericidal drug Ampicilin. The complexes $\mathbf{C 1}, \mathbf{C} \mathbf{4}$ and $\mathbf{C 5}$ demonstrate the significant antifungal activity against the pathogen Candida albicans, depicted the largest zone of inhibition $19.25 \mathrm{~mm}, 16.43 \mathrm{~mm}$ and $16.58 \mathrm{~mm}$, respectively, which were higher than zone of inhibition $16.24 \mathrm{~mm}$ of fungicidal drug Fluconazole. However, all the complexes showed moderate antibacterial activity against the pathogen Escherichia coli, depicted the lower zone of inhibition with respect to bactericidal drug Ampicilin. 


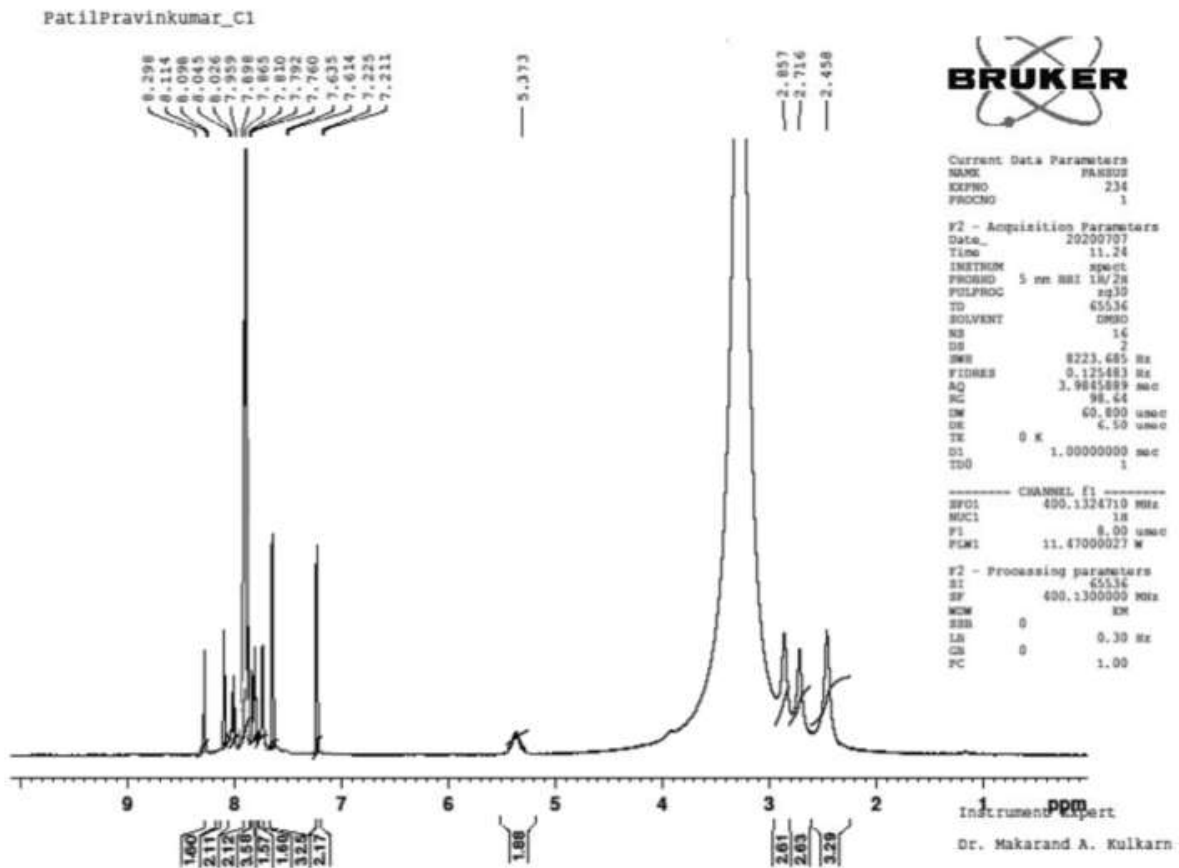

Figure 4. ${ }^{1} \mathrm{H}$ NMR spectrum of complex $\left[\mathrm{Co}\left(\mathrm{C}_{19} \mathrm{H}_{10} \mathrm{O}_{3} \mathrm{I}_{3}\right)_{2} \cdot 2 \mathrm{H}_{2} \mathrm{O}\right](\mathbf{C 1})$.

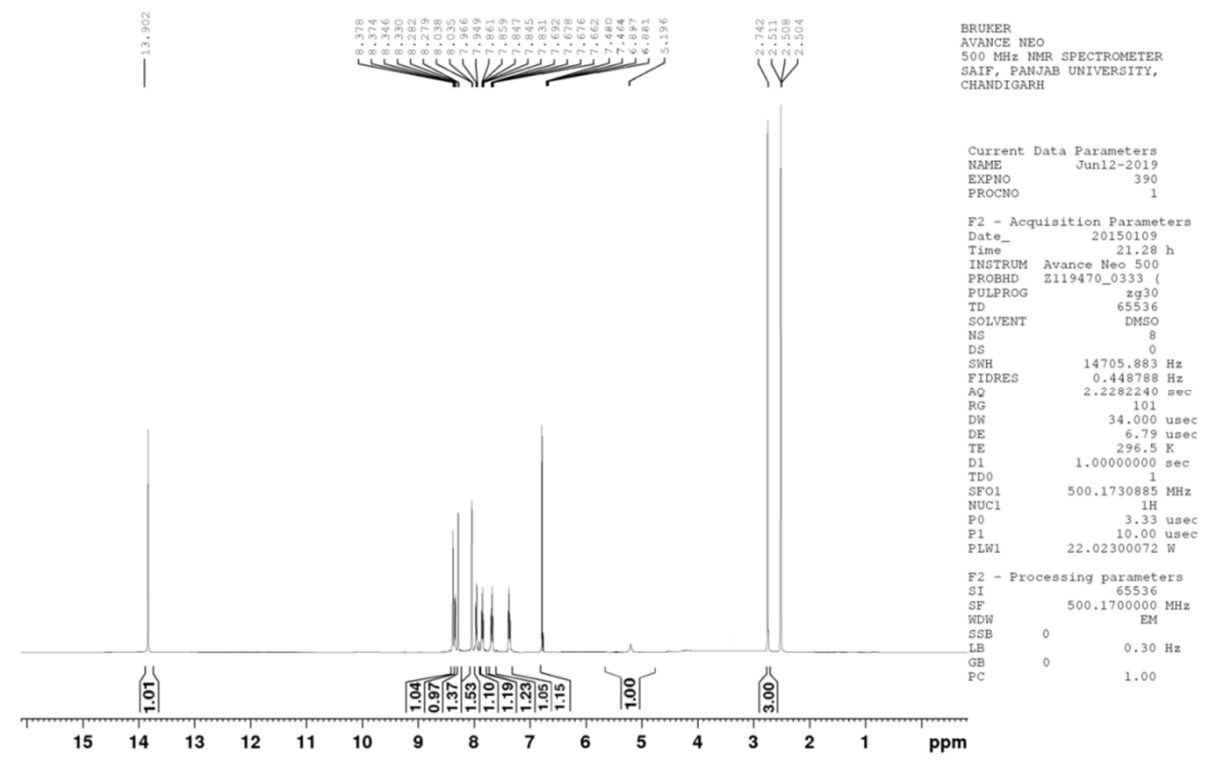

Figure 5. ${ }^{1} \mathrm{H}$ NMR spectrum of ligand (L1).

Bull. Chem. Soc. Ethiop. 2021, 35(3) 


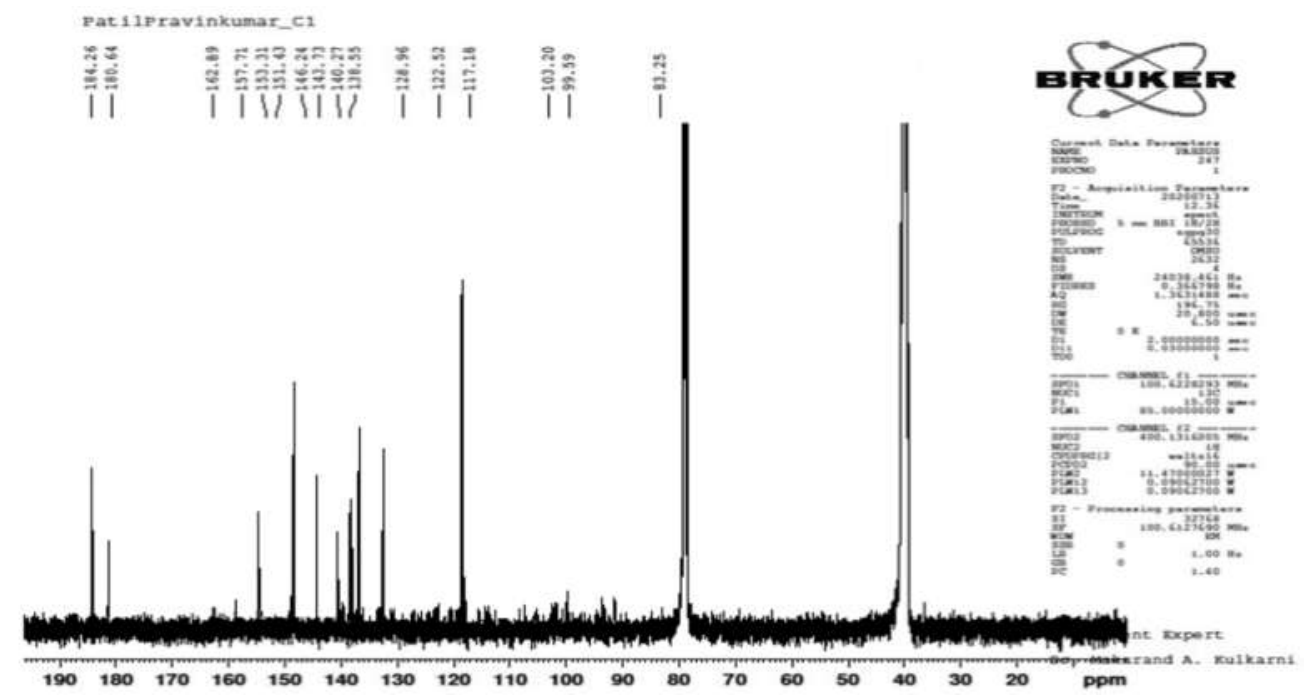

Figure $6 .{ }^{13} \mathrm{C}$ NMR spectrum of complex $\left[\mathrm{Co}\left(\mathrm{C}_{19} \mathrm{H}_{10} \mathrm{O}_{3} \mathrm{I}_{3}\right)_{2} \cdot 2 \mathrm{H}_{2} \mathrm{O}\right](\mathbf{C 1})$.

Consequently, the complexes C1, C4, C5 and C6 showed the even higher activity index with respect to strain and standard drugs, indicates significant potency. Activity data showed that inhibition found enhanced in all complexes than its respective ligand. Structurally similar activity data were reported in our previous study for $\mathrm{Cu}(\mathrm{II})$ and $\mathrm{Zn}$ (II) complexes of 2'-hydroxy chalcones [30]. The reason is that synthesized complexes contain di-dentate coordinating sites, their ligands associated with multiple halogen or hydroxyl substituents. These substituent supports to boost the pharmacological activity. The activity index (A.I.) was calculated using average zone of inhibition by following formula.

$$
\text { Activity index (A. I. ) }=\frac{\text { Mean zone of inhibition of derivatives }}{\text { Zone of inhibition of standard drug }}
$$

The minimum inhibitory concentrations of complexes were performed at the concentrations $1.0,0.5,0.25$ and $0.12 \mathrm{mg} / \mathrm{mL}$. The observed MIC values of complexes and respective ligands are presented in Table 4. The complex C1 was most sensitive, being inhibited at MIC value 0.12 $\mathrm{mg} / \mathrm{mL}$ against all pathogens with respect to the standard drug Ampicilin and Flucanozole inhibited at MIC values $0.25 \mathrm{mg} / \mathrm{mL}$ and $1.0 \mathrm{mg} / \mathrm{mL}$, respectively. The complexes $\mathbf{C 2}, \mathbf{C 5}$ and C6 were most potent, being inhibited at MIC values $0.12 \mathrm{mg} / \mathrm{mL}$ against the pathogen Escherichia coli with respect to the standard drug Ampicilin inhibited at MIC values $0.25 \mathrm{mg} / \mathrm{mL}$. The complexes C2, C4 and C5 were the most resistant, being inhibited at MIC values $0.12 \mathrm{mg} / \mathrm{mL}$ against the pathogen Candida albicans with respect to the standard drug Flucanozole inhibited at MIC values $1.0 \mathrm{mg} / \mathrm{mL}$. All complexes showed the improved MIC values than the respective ligands. The increased potency is due to the presence of halogens or hydroxyl substitutes in the ligands. 
Table 3. Antimicrobial activity of complexes and their ligands.

\begin{tabular}{|c|c|c|c|c|c|c|}
\hline \multirow[b]{3}{*}{ Compound } & \multicolumn{4}{|c|}{ Antibacterial } & \multirow{2}{*}{\multicolumn{2}{|c|}{$\begin{array}{l}\text { Antifungal } \\
\text { C. albicans }\end{array}$}} \\
\hline & \multicolumn{2}{|c|}{ S. aureus } & \multicolumn{2}{|c|}{ E. coli } & & \\
\hline & $\begin{array}{l}\text { Average } \\
\text { zone of } \\
\text { inhibition } \\
\text { (in mm) }\end{array}$ & $\begin{array}{l}\text { Activity } \\
\text { index } \\
\text { (A.I.) }\end{array}$ & $\begin{array}{l}\text { Average } \\
\text { zone of } \\
\text { inhibition } \\
\text { (in mm) }\end{array}$ & $\begin{array}{l}\text { Activity } \\
\text { index } \\
\text { (A.I.) }\end{array}$ & $\begin{array}{l}\text { Average } \\
\text { zone of } \\
\text { inhibition } \\
\text { (in mm) }\end{array}$ & $\begin{array}{l}\text { Activity } \\
\text { index } \\
\text { (A.I.) }\end{array}$ \\
\hline $\mathrm{L}_{1}{ }^{*}$ & - & 1.2471 & - & 0.8358 & - & 1.0313 \\
\hline $\mathrm{C} 1:\left[\mathrm{Co}\left(\mathrm{L}_{1}\right)_{2}\right] .2 \mathrm{H}_{2} \mathrm{O}$ & 23.62 & 1.3021 & 17.47 & 0.9045 & 19.25 & 1.1858 \\
\hline $\mathrm{L}_{2} *$ & - & 0.5914 & - & 0.8749 & - & 0.82447 \\
\hline $\mathrm{C} 2:\left[\mathrm{Co}\left(\mathrm{L}_{2}\right)_{2}\right] \cdot 2 \mathrm{H}_{2} \mathrm{O}$ & 12.51 & 0.6897 & 18.78 & 0.9725 & 15.77 & 0.9713 \\
\hline $\mathrm{L}_{3} *$ & - & 0.8044 & - & 0.6854 & - & 0.7051 \\
\hline $\mathrm{C} 3:\left[\mathrm{Co}\left(\mathrm{L}_{3}\right)_{2}\right] .2 \mathrm{H}_{2} \mathrm{O}$ & 16.75 & 0.9234 & 15.11 & 0.7824 & 14.32 & 0.8821 \\
\hline $\mathrm{L}_{4} *$ & - & 0.8131 & - & 0.6981 & - & 0.8629 \\
\hline $\mathrm{C} 4:\left[\mathrm{Co}\left(\mathrm{L}_{4}\right)_{2}\right] .2 \mathrm{H}_{2} \mathrm{O}$ & 17.15 & 0.9456 & 15.04 & 0.7785 & 16.43 & 1.0122 \\
\hline $\mathrm{L}_{5} *$ & - & 0.7841 & - & 0.8309 & - & 0.8422 \\
\hline $\mathrm{C} 5:\left[\mathrm{Co}\left(\mathrm{L}_{5}\right)_{2}\right] \cdot 2 \mathrm{H}_{2} \mathrm{O}$ & 16.91 & 0.9325 & 19.47 & 0.9914 & 16.58 & 1.0215 \\
\hline $\mathrm{L}_{6} *$ & - & 0.8218 & - & 0.7096 & - & 0.7707 \\
\hline $\mathrm{C} 6:\left[\mathrm{Co}\left(\mathrm{L}_{6}\right)_{2}\right] .2 \mathrm{H}_{2} \mathrm{O}$ & 18.36 & 1.0125 & 18.86 & 0.9765 & 15.67 & 0.9654 \\
\hline DMSO & No zone & - & No zone & - & No zone & - \\
\hline Ampicilin & 18.14 & 1.0000 & 19.32 & 1.0000 & - & - \\
\hline Fluconazole & -- & - & --- & - & 16.24 & 1.0000 \\
\hline
\end{tabular}

* Growth inhibitory activity of ligand against tested pathogens [29].

Table 4. MIC values of complexes and their ligands.

\begin{tabular}{|c|c|c|c|}
\hline \multirow{2}{*}{ Ligand and complex } & \multicolumn{3}{|c|}{ MIC in $\mathrm{mg} / \mathrm{mL}$} \\
\cline { 2 - 4 } & S. aureus & E. coli & C. albicans \\
\hline $\mathrm{L}_{1}{ }^{*}$ & 0.12 & 0.25 & 0.12 \\
\hline $\mathrm{C} 1:\left[\mathrm{Co}\left(\mathrm{L}_{1}\right)_{2}\right] \cdot 2 \mathrm{H}_{2} \mathrm{O}$ & $\mathbf{0 . 1 2}$ & $\mathbf{0 . 1 2}$ & $\mathbf{0 . 1 2}$ \\
\hline $\mathrm{L}_{2}{ }^{*}$ & 0.50 & 0.25 & 0.25 \\
\hline $\left.\mathrm{C} 2:\left[\mathrm{Co}_{2}\right)_{2}\right] \cdot 2 \mathrm{H}_{2} \mathrm{O}$ & 0.50 & $\mathbf{0 . 1 2}$ & $\mathbf{0 . 1 2}$ \\
\hline $\left.\mathrm{L}_{3}{ }^{*}\right)_{2}$ & 0.50 & 1.0 & 0.0 \\
\hline $\mathrm{C} 3:\left[\mathrm{Co}\left(\mathrm{L}_{3}\right)_{2}\right] \cdot 2 \mathrm{H}_{2} \mathrm{O}$ & 0.25 & 0.25 & 0.25 \\
\hline $\mathrm{L}_{4}{ }^{*}$ & 0.25 & 0.50 & $\mathbf{0 . 1 2}$ \\
\hline $\mathrm{C} 4:\left[\mathrm{Co}\left(\mathrm{L}_{4}\right)_{2}\right] \cdot 2 \mathrm{H}_{2} \mathrm{O}$ & $\mathbf{0 . 1 2}$ & 0.25 & 0.25 \\
\hline $\mathrm{L}_{5}{ }^{*}$ & 0.50 & 0.25 & $\mathbf{0 . 1 2}$ \\
\hline $\mathrm{C} 5:\left[\mathrm{Co}\left(\mathrm{L}_{5}\right)_{2}\right] \cdot 2 \mathrm{H}_{2} \mathrm{O}$ & 0.25 & $\mathbf{0 . 1 2}$ & 0.50 \\
\hline $\mathrm{L}_{6}{ }^{*}$ & 0.25 & 0.50 & 0.25 \\
\hline $\mathrm{C} 6:\left[\mathrm{Co}\left(\mathrm{L}_{6}\right)_{2}\right] .2 \mathrm{H}_{2} \mathrm{O}$ & 0.25 & $\mathbf{0 . 1 2}$ & \\
\hline Ampicilin & 0.25 & 0.25 & 1.0 \\
\hline Fluconazole & & & \\
\hline
\end{tabular}

*Displays the MIC of ligands [29].

\section{CONCLUSION}

A series of bi-coordinated $\mathrm{Co}$ (II) complexes with 1,3-diaryl-2-propene-1-ones derivatives have been synthesized. All synthesized complexes have been spectrally characterised by IR, NMR, TGA, XRD and EPR analysis. The data suggested the octahedral geometry of Co(II) and bidentate ligands complexes with 1:2 stoichiometry. The in-vitro antimicrobial activity of complexes evaluated against the gram positive bacteria Staphylococcus aureus, gram negative bacteria Escherichia coli and the yeast Candida albicans. All these complexes showed much improved antimicrobial activity than its ligands associated with halogen and hydroxyl moiety. The complex 
C1 showed significant activity against all tested pathogens. The complexes C2, C5 and C6 showed significant activity against the Escherichia coli and Candida albicans and the complexes C4 showed significant activity against the Staphylococcus aureus and Candida albicans. The complex $\mathbf{C 1}$ exhibited the MIC value of $0.12 \mathrm{mg} / \mathrm{mL}$ against all pathogens, the complex $\mathbf{C} 2$ and C5 showed the MIC value of $0.12 \mathrm{mg} / \mathrm{mL}$ against Escherichia coli and Candida albicans, whereas the complex C4 showed the MIC value of $0.12 \mathrm{mg} / \mathrm{mL}$ against Staphylococcus aureus and Candida albicans. Hence, this synthetic methodology and antimicrobial results might serve as preliminary screening for the development of new antimicrobial agents with structural modification.

\section{ACKNOWLEDGEMENTS}

The authors are very thankful to Panjab University, Chandigarh for instrumental analysis and Tuljaram Chaturchand College, Baramati for assistance of biological activity.

\section{REFERENCES}

1. Dan, W.; Dai, J. Recent developments of chalcones as potential antibacterial agents in medicinal chemistry. Eur. J. Med. Chem. 2020, 187, 111980.

2. Asiri, A.M.; Khan, S.A. Synthesis and antibacterial activities of bis-chalcone derived from thiophene and its bis-catalyzed products. Molecule 2011, 16, 523-531.

3. Kakati, D.; Sarma, J.C. Microwave assisted solvent free synthesis of 1,3-diphenylpropenones. Chem. Cen. J. 2011, 5, 1-5.

4. Albuquerque, H.; Santos, C.; Cavaleiro, J.; Silva, A. Chalcones as vesatile synthons for the synthesis of 5- and 6-membered nitrogen hetrocycles. Curr. Org. Chem. 2014, 18, 2750-2775.

5. Biradar, J.S.; Sasidhar, B.S.; Parveen, R. Synthesis, antioxidant and DNA cleavage activities of novel indole derivatives. Eur. J. Med. Chem. 2010, 45, 4074-4078.

6. Nowakowska, Z. A review of anti-infective and anti-inflammtory chalcones. Eur. J. Med. Chem. 2007, 42, 125-137.

7. Kumar, D.; Kumar, N.M.; Akamatsu, K.; Kusaka, E.; Harada, H.; Ito, T. Synthesis and biological evaluation of indolyl chalcones as antitumor agents. Bioorg. Med. Chem. Lett. 2010, 20, 3916-3919.

8. Kamal, A.; Mallareddy, A.; Suresh , P.; Shaik, T.B., Lakshma Nayak, V.; Kishor, C.; Shetti, R.; Sankara Rao, N.; Tamboli, J.R.; Ramakrishna, S.; Addlagatta, A. Synthesis of chalconeamidobenzothiazole conjugates as antimitotic and apoptotic inducing agents. Bioorg. Med. Chem. 2012, 20, 3480-3492.

9. Husain, A.; Rashid, M.; Mishra, R.; Kumar, D. Bis-chalcones and flavones: Synthesis and antimicrobial activity. Acta Pol. Pharm. 2013, 70, 443-449.

10. Mirande, C.L.; Stevens, J.F.; Ivanov, V.; McCall, M.; Frei, B.; Deinzer, M.L.; Buhler, D.R. Antioxidant and prooxidant actions of prenylated and nonprenylated chalcones and flavanones in vitro. J. Agric. Food Chem. 2000, 48, 3876-3884.

11. Rammohan, A.; Bhaskar, B.; Venkateswarlu, N.; Gu, W.; Zyryanov, G.V. Design, synthesis, docking and biological evaluation of chalcones as promising antidiabetic agents. Bioorg. Chem. 2020, 95, 103527.

12. Liu, M.; Wilairat, P.; Go, M.L. Antimalarial alkoxylated and hydroxylated chalones: Structure-activity relationship analysis. J. Med. Chem. 2001, 44, 4443-4452.

13. Atlam, F.M.; El-Nahass, M.N.; Bakr, E.A.; Fayed, T.A. Metal complexes of chalcone analogue: Synthesis, characterization, DNA binding, molecular docking and antimicrobial evaluation. Appl. Organometal. Chem. 2017, e3951, 1-24.

14. Ali, M.F.; Khlafulla, A.M. Friendly and efficient synthesis of chalcone derivatives under solvent free condition. Res. Rev. J. Pharm. 2016, 6, 1-8. 
15. Mahapatra, D.; Bharti, S.; Asati, V.; Singh, S. Perspectives of medicinally privileged chalcone based metal coordination compounds for biomedical applications. Eur. J. Med. Chem. 2019, $174,142-158$

16. Sulpizio, C.; Breibeck, J.; Rompel, A. Recent progress in synthesis and characterization of metal chalcone complexes and their potential as bioactive agents. Coord. Chem. Rev. 2018, 374, 497-524.

17. Agharia, E.R. Study of effect of strong resonance stabilized intramolecular hydrogen bonding in 1-(1-hydroxy-2-naphthyl)-3-(phenyl or substituted phenyl)-prop-2-en-1-ones and on their complexation with some transition metals through ${ }^{1} \mathrm{H}-\mathrm{NMR}$ and electronic spectroscopic investigations. J. Appl. Chem. 2014, 3, 1059-1072.

18. Shagufta; Ahmad, I. Transition metal complexes as proteasome inhibitors for cancer treatment. Inorg. Chim. Acta 2020, 506, 119521.

19. Kendur, U.; Chimmalagi, G.H.; Patil, S.M.; Gudasi, K.B.; Frampton, C.S.; Mangannavar, C.V.; Muchchandi, I.S. Mononuclear late first row transition metal complexes of ONO donor hydrazone ligand: Synthesis, characterization, crystallographic insight, in vivo and in vitro antiinflammatory activity. J. Mol. Struct. 2018, 1153, 299-310.

20. Shchur, I.V.; Shchegolkov, E.V.; Burgart, Ya.V.; Kozitsina, A.N.; Ivanova, A.V.; Alyamovskaya, I.S.; Evstigneeva, N.P.; Gerasimova, N.A.; Ganebnykh, I.N.; Zilberberg, N.V.; Kungurov, N.V.; Saloutin, V.I.; Chupakhin, O.N. Metal complexes based on polyfluorosalicylic acids and their antimycotic and antimicrobial activity. Polyhedron 2020, 177,114279

21. Gomes, L.M.F.; Bataglioli, J.C.; Storr, T. Metal complexes that bind to the amyloid- $\beta$ peptide of relevance to Alzheimer's disease. Coord. Chem. Rev. 2020, 412, 213255.

22. Kumar, A.; Kumar, D.; Kumari, K.; Mkhize, Z.; Katata Seru, L.M.; Bahdur, I.; Singh, P. Metal-ligand complex formation between ferrous or ferric ion with syringic acid and their anti-oxidant and anti-microbial activities: DFT and molecular docking approach. J. Mol. Liq. 2021, 322, 114872.

23. Khan, S.; Tariq, M.; Ashraf, M.; Abdullah, S.; Al-Rashida, M.; Khalid, M.; Taslimi, P.; Fatima, M.; Zafar, R.; Shafiq, Z. Probing 2-acetylbenzofuran hydrazones and their metal complexes as $\alpha$-glucosidase inhibitors. Bioorg. Chem. 2020, 102, 104082.

24. Edozie, O.I.; Godday, O.J.; Chijioke, A.K; Uchenna, I.O.; Chigozie, N.F. Synthesis, characterization and molecular docking studies of $\mathrm{Co}(\mathrm{II})$ metal complex of sulfathiazole. Bull. Chem. Soc. Ethiop. 2020, 34, 83-92.

25. Turunc, E.; Gumus, I.; Arslan, H. Redox active Co(II) complex modified carbon paste electrode for the determination of dopamine. Mater. Chem. Phys. 2020, 243, 122597.

26. Bhattacharya, P.T.; Misra, S. R.; Hussain, M. Nutritional aspects of essential trace elements in oral health and disease: An extensive review. Scientifica 2016, Article ID 5464373, 1-12.

27. Miodragovic, D.U.; Bogdanovic, G.A.; Miodragovic, Z.M.; Radulovic, M.D.; Novakovic, S.B.; Kaluderovic, G.N.; Kozlowski, H. Interesting coordination abilities of antiulcer drugfamotidine and antimicrobial activity of drug and its cobalt(III) complex. J. Inorg. Biochem. 2006, 100, 1568-1574.

28. Mohamad, A.D.M.; Abualreish, M.J.A.; Abu-Dief, A.M. Antimicrobial and anticancer activities of cobalt(III)-hydrazone complexes: Solubilities and chemical potentials of transfer in different organic co-solvent-water mixtures. J. Mol. Liq. 2019, 290, 111162.

29. Patil, P.; Khan, P.A.; Zangade, S. Synthesis of 1,3-diaryl-2-propene-1-one derivatives using tripotassium phosphate as an alternative and efficient catalyst and study its cytotoxic and antimicrobial activity. Curr. Chem. Lett. 2020, 9, 183-198.

30. Patil, P.; Zangade, S. Synthesis, characterization, antimicrobial screening and cytotoxic properties of $\mathrm{Cu}(\mathrm{II})$ and $\mathrm{Zn}$ (II) complexes with a bidentatehydroxylated 1,3-diaryl-2propene-1-one ligand. J. Serb. Chem. Soc. 2021, 86, 153-164. 